\title{
ANALISIS KINERJA SISTEM PANCI BERTEKANAN PADA SISTEM KONSENTRATOR SURYA TIPE PARABOLA
}

\section{Performance Analysis of Pressure Pan System in the Solar Parabolic Concentrator System}

\author{
Ropiudin $^{1, *}$, Furqon ${ }^{1}$, Rizki Hardi ${ }^{2}$ \\ ${ }^{1}$ Program Studi Teknik Pertanian - Jurusan Teknologi Pertanian - Fakultas Pertanian - Universitas \\ Jenderal Soedirman \\ ${ }^{2}$ UPTD Pengelolaan Sumber Daya Air wilayah Sungai Cimanuk - Cisanggarung Provinsi Jawa Barat \\ *Korespondensi, Email: ropiudin@unsoed.ac.id
}

DOI: https://doi.org/10.20884/1.jaber.2021.2.1.4466

Naskah ini diterima pada 3Juni 2021; revisi pada 13 Juni 2020;

disetujui untuk dipublikasikan pada 15 Juni 2021

\begin{abstract}
ABSTRAK
Energi surya merupakan salah satu sumber energi terbarukan yang potensial untuk memenuhi kebutuhan energi dalam kehidupan. Jumlah energi surya yang sampai ke permukaan bumi yang dikenali sebagai konstan surya menyamai $1.350 \mathrm{~W} / \mathrm{m}^{2}$ setiap saat, ditambah dengan letak geografis Indonesia yang berada di garis khatulistiwa menjadikan energi surya sangat potensial untuk dikembangkan sebagai salah satu energi alternatif pengganti energi fosil. Teknologi untuk memanfaatkan tenaga surya yang telah digunakan sejauh ini yaitu teknologi surya photovoltaic maupun teknologi panas surya (Solar-Thermal). Energi panas surya pada umumnya digunakan untuk memasak (kompor surya), dan mengeringkan hasil pertanian. Tujuan dari penelitian ini adalah, (1) Mengetahui suhu optimum yang dihasilkan dari proses termal pada sistem panci bertekanan konsentrator surya tipe parabola, (2) mengetahui tekanan optimum yang dihasilkan dari proses termal yang terjadi pada sistem panci bertekanan konsentrator surya termal tipe parabola, dan (3) mengetahui tingkat efisiensi sistem yang dapat dicapai berdasarkan peristiwa pindah panas yang terjadi pada sistem panci bertekanan konsentrator surya tipe parabola. Penelitian ini berfokus kepada uji kinerja dari sistem panci bertekanan yang merupakan salah satu komponen pada sistem konsentrator surya tipe parabola. Analisis data yang digunakan pada penelitian ini menggunakan analisis data kuantitatif dengan mencari hubungan dua variabel. Mencari hubungan dan membandingkan antara intensitas cahaya matahari yang diterima dengan perubahan suhu pada sistem prototipe panci bertekanan terhadap waktu. Analisis data perpindahan panas yang terjadi pada sistem panci bertekanan terhadap perubahan intensitas radiasi matahari, serta efisiensi yang dapat diraih sistem panci pada kondisi iradiasi terukur. Hasil penelitian menunjukkan bahwa: (1) Suhu optimum yang dapat diraih dari prototipe sistem panci berdasarkan 2 data yang telah dipilih adalah pada bagian dasar-luar panci adalah $224,2^{\circ} \mathrm{C}$, untuk bagian dasar-dalam panci sebesar $202,5{ }^{\circ} \mathrm{C}$, dinding-dalam panci $=131,2{ }^{\circ} \mathrm{C}$, tutup panci $=98,2^{\circ} \mathrm{C}$, dan dinding-luar panci (tertutup glasswool) $=84,7^{\circ} \mathrm{C}$. (2) Prototipe sistem panci bertekanan ini dapat menghasilkan tekanan optimum sebesar 0,15 bar atau setara dengan $15 \mathrm{kPa}$ ketika menggunakan air sebagai fluida kerja, sedangkan ketika memakai minyak belum mampu menghasilkan tekanan. (3) Nilai kalor optimal prototipe sistem yang dihasilkan saat proses termal dari 2 data terbaik adalah pada bagian dasar-luar ke dalam $=192,34 \mathrm{~kW}$, dasar dalam ke fluida $=9,8 \mathrm{~kW}$, fluida ke dinding dalam $=40,16 \mathrm{~kW}$, dan bagian dinding dalam ke luar = 171,09 kW. (4) Efisiensi termal optimum yang dapat dihasilkan oleh prototipe sistem panci bertekanan adalah sebesar 88,97\%, pada kondisi radiasi matahari $1120 \mathrm{~W} / \mathrm{m}^{2}$.
\end{abstract}

Kata kunci: energi, efisiensi, panci bertekanan, konsentrator surya tipe parabola, energi terbarukan

\section{ABSTRACT}

Solar energy is one of the potential renewable energy sources to meet the energy needs of life. The amount of solar energy reaching the earth's surface which is known as the solar constant equals 1,350 
$\mathrm{W} / \mathrm{m}^{2}$ at any time, coupled with Indonesia's geographical location at the equator, making solar energy very potential to be developed as an alternative energy to replace fossil energy. The technology to utilize solar power that has been used so far is photovoltaic solar technology and solar thermal technology (Solar-Thermal). Solar thermal energy is generally used for cooking (solar stoves), and drying agricultural products. The aims of this study are, (1) to determine the optimum temperature resulting from the thermal process in the parabolic solar concentrator pressure cooker system, (2) to determine the optimum pressure resulting from the thermal process that occurs in the solar parabolic concentrator with pressure cooker system, and (3) determine the level of system efficiency that can be achieved based on heat transfer events that occur in a solar parabolic concentrator with pressure cooker system. This research focuses on testing the performance of the pressure cooker system which is one component of the solar parabolic concentrator system. Analysis of the data used in this study using quantitative data analysis by looking for the relationship between two variables. Look for the relationship and compare the intensity of sunlight received with changes in temperature in the pressure cooker prototype system with time. Analysis of heat transfer data that occurs in the pressure cooker system to changes in the intensity of solar radiation, as well as the efficiency that can be achieved by the pan system under measured irradiation conditions. The results show that: (1) The optimum temperature that can be achieved from the prototype of the pan system based on the 2 data that have been selected is at the bottom-outside of the pan is $224.2^{\circ} \mathrm{C}$, for the bottom-inside of the pan is $202.5^{\circ} \mathrm{C}$, inside the pot $=131.2^{\circ} \mathrm{C}$, the lid of the pot $=$ $98.2^{\circ} \mathrm{C}$, and the outside of the pan (covered with glass wool) $=84.7^{\circ} \mathrm{C}$. (2) The prototype of this pressure cooker system can produce an optimum pressure of 0.15 bar or equivalent to $15 \mathrm{kPa}$ when using water as the working fluid, whereas when using oil it is not able to produce pressure. (3) The optimal calorific value of the prototype system produced during the thermal process from the 2 best data is at the bottomoutside to inside $=192.34 \mathrm{~kW}$, bottom to the fluid $=9.8 \mathrm{~kW}$, fluid to the inner wall $=40.16 \mathrm{~kW}$, and the inside to the outside $=171.19 \mathrm{~kW}$. (4) The optimum thermal efficiency that can be produced by the prototype of the pressure cooker system is $88.97 \%$, at $1120 \mathrm{~W} / \mathrm{m}^{2}$ solar radiation conditions.

Keywords: energy, efficiency, pressure cooker, solar parabolic concentrator, renewable energy

\section{PENDAHULUAN}

Kebutuhan energi saat ini masih didominasi oleh sumber energi yang tidak dapat diperbaharui, yaitu energi fosil. Seiring berjalannya waktu, pada akhirnya energi fosil yang tersedia di alam bisa habis, yang dapat menyebabkan terjadinya krisis sumber energi. Perlu adanya inovasi baru untuk upaya pencegahan terjadinya krisis energi. Pengembangan energi alternatif secara intensif perlu dilakukan sebagai solusi dalam mengatasi kelangkaan sumber energi yang dapat menyebabkan krisis sumber energi.

Energi surya merupakan salah satu sumber energi terbarukan yang potensial untuk memenuhi kebutuhan energi dalam kehidupan. Jumlah energi surya yang sampai ke permukaan bumi yang dikenali sebagai konstan surya menyamai $1.350 \mathrm{~W} / \mathrm{m}^{2}$ setiap saat, ditambah dengan letak geografis Indonesia yang berada di garis khatulistiwa menjadikan energi surya sangat potensial untuk dikembangkan sebagai salah satu energi alternatif pengganti energi fosil.

Pemanfaatan panas matahari di Indonesia masih menggunakan cara tradisional. Masyarakat biasanya memanfaatkan energi panas matahari hanya sebatas untuk mengeringkan bahan pertanian serta untuk kebutuhan sehari-hari. Saat ini, pemanfaatan energi panas surya sendiri sudah mulai dikembangkan seperti menggunakan suatu sistem, seperti sistem kolektor maupun konsentrator.

Teknologi untuk memanfaatkan tenaga surya yang telah digunakan sejauh ini yaitu teknologi surya photovoltaic maupun teknologi panas surya (solar-thermal). Energi panas surya pada umumnya digunakan untuk memasak (kompor surya), dan mengeringkan hasil pertanian. Energi surya fotovoltaik digunakan untuk memenuhi kebutuhan listrik.

Pada sistem pemanfaatan solar thermal menggunakan konsentrator bertumpu pada mengkonsentrasikan panas yang terbawa bersama cahaya matahari, kemudian dimanfaatkan untuk memanaskan fluida cair pada sebuah sistem pemanas (heater). Fluida yang dipanaskan tentunya akan mencapai titik didih yang tinggi, akan tetapi untuk meningkatkan titik didih fluida cair sampai pada kondisi panas optimal yang nantinya dapat dimanfaatkan, beberapa 
diantaranya yaitu untuk sumber panas pada alat pengering serta dapat menjadi media untuk menghasilkan energi listrik. Proses termal pada fluida cair dapat dimanfaatkan untuk pengeringan apabila memenuhi kondisi yang telah ditentukan. Perlakuan diperlukan guna menghasilkan sumber panas yang cukup, salah satu cara dengan memanfaatkan tekanan.

\section{Kondisi Kebutuhan Energi di Indonesia}

Kebutuhan energi saat ini masih didominasi oleh sumber energi yang tidak dapat diperbaharui, yaitu energi fosil. Seperti yang telah diketahui, bahwa energi fosil untuk saat ini semakin menipis, sehingga perlu adanya inovasi guna mengantisipasi kelangkaan sumber energi. Bagi Indonesia masalah energi menjadi lebih penting lagi artinya dan perlu mendapatkan penanganan yang khusus dikarenakan (Manan, 2006): (1) Lebih kurang 80\% kebutuhan energi di Indonesia dipenuhi oleh minyak bumi (data 2002), (2) Harga minyak dan Konsumsi minyak bumi yang cenderung meningkat dengan pesat setiap tahun, dan (3) Banyaknya sumber-sumber alternatif di Indonesia yang perlu dikembangkan.

Perpres Nomor 5 Tahun 2006 Tentang Kebijakan Energi Nasional (KEN) menunjukkan adanya upaya agar pemakaian energi baru dan terbarukan meningkat. Energi terbarukan adalah sumber energi yang dihasilkan dari sumberdaya energi yang secara alamiah tidak akan habis dan dapat berkelanjutan jika dikelola dengan baik, antara lain energi surya, panas bumi, bahan bakar nabati (biofuel), arus sungai, energi angin, biomassa, dan energi laut (Kementerian ESDM, 2006).

\section{Energi Surya Sebagai Energi Alternatif}

Energi surya merupakan salah satu sumber energi terbarukan yang potensial untuk memenuhi kebutuhan energi dalam kehidupan. Intensitas radiasi matahari di luar atmosfer bumi, tergantung pada jarak antara matahari dengan bumi. Tiap tahun, jarak ini bervariasi antara 1.47 x $108 \mathrm{~km}$ dan 1.52 x $108 \mathrm{~km}$. Hasilnya, besar pancaran $\mathrm{E}_{0}\left(1367 \mathrm{~W} / \mathrm{m}^{2}\right)$ naik turun antara 1325 $\mathrm{W} / \mathrm{m}^{2}$ dan $1412 \mathrm{~W} / \mathrm{m}^{2}$. Nilai rata-ratanya disebut sebagai konstanta matahari (Sterling, 2005 dalam Setiawan et al., 2011)

Berdasarkan data penyinaran matahari yang dihimpun dari 18 lokasi di Indonesia, radiasi surya di Indonesia dapat diklasifikasikan berturut-turut sebagai berikut: untuk kawasan Barat dan Timur Indonesia dengan distribusi penyinaran di Kawasan Barat Indonesia sekitar 4,5 $\mathrm{kWh} / \mathrm{m}^{2}$ per hari dengan variasi bulanan sekitar $10 \%$ dan di Kawasan Timur Indonesia sekitar $5,1 \mathrm{kWh} / \mathrm{m}^{2}$ per hari dengan variasi bulanan sekitar 9\%. Dengan demikian, potensi energi matahari rata-rata Indonesia sekitar $4,8 \mathrm{kWh} / \mathrm{m}^{2}$ per hari dengan variasi bulanan sekitar $9 \%$ (Kementrian ESDM, 2011 dalam Rahman et al., 2013).

Menurut Manan (2006) bahwa saat keadaan cuaca cerah, permukaan bumi menerima sekitar $1000 \mathrm{~W}$ energi matahari per-meter persegi. Kurang dari 30\% energi tersebut dipantulkan kembali ke angkasa, 47\% dikonversikan menjadi panas, 23\% digunakan untuk seluruh sirkulasi kerja yang terdapat di atas permukaan bumi, sebagaian kecil 0,25\% ditampung angin, gelombang dan arus dan masih ada bagian yang sangat kecil 0,025\% disimpan melalui proses fotosintesis di dalam tumbuh-tumbuhan, sehingga bisa dikatakan bahwa sumber segala energi adalah energi matahari.

Energi matahari mempunyai kelebihan, yaitu kita tidak perlu membayar untuk memperolehnya, akan tetapi mempunyai kelemahan karena tidak konstan intensitasnya. Bila energi matahari dapat dimanfaatkan untuk memasak walaupun sebagai energi pembantu disamping LPG, maka penghematan diperkirakan diantara 30-50\% (tergantung cuaca). Dihitung secara biaya tiap rumah tangga pada umumnya tidak terlalu besar tetapi pada skala nasional cukup signifikan (Novitasari, 2012).

\section{Energi Termal Matahari}

Energi termal dari matahari banyak dimanfaatkan oleh petani untuk mengeringkan bahan-bahan yang telah dipanen. Selain petani, masyarakat umum, terutama di daerah dingin 
memanfaatkan energi surya termal untuk kebutuhannya sehari-hari, salah satunya pemanas air tenaga surya (solar water heater).

Selain dimanfaatkan untuk kebutuhan sehari-hari, beberapa penelitian menunjukkan bahwa, energi termal matahari juga dapat dimanfaatkan sebagai penghasil energi listrik. Penelitian tentang Pembangkit Listrik Surya Termal secara komersial pertama kali dikembangkan pada tahun 1980. Diperkirakan oleh US National Laboratories Energi Terbarukan dari tenaga panas matahari bisa menyediakan ratusan gigawatt listrik, sama dengan lebih dari 10 persen dari permintaan listrik di Amerika Serikat.

Pembangkit Listrik Termal Surya dapat bekerja dalam berbagai cara. Pembangkit ini juga biasa dikenal sebagai pembangkit listrik surya terkonsentrasi (concentrated solar power plants). Tipe yang paling banyak digunakan adalah desain parabola cekung. Cermin parabola dirancang untuk menangkap dan memfokuskan berkas cahaya ke satu titik fokus, seperti seorang anak yang menggunakan kaca pembesar untuk membakar kertas. Pada titik fokus tersebut terdapat pipa hitam yang panjangnya sepanjang cermin tersebut. Didalam pipa tersebut terdapat fluida yang dipanaskan hingga temperatur yang sangat tinggi, seringkali diatas $300{ }^{\circ} \mathrm{F}$ $\left(150{ }^{\circ} \mathrm{C}\right)$. Fluida panas tersebut dialirkan dalam pipa menuju ke ruang pembangkitan energi listrik untuk memasak air, menghasilkan uap air dan menghasilkan energi listrik.

\section{Prinsip Termodinamika}

Termodinamika berasal dari dua kata yaitu thermal (yang berkenaan dengan panas) dan dinamika (yang berkenaan dengan pergerakan). Termodinamika adalah ilmu dimana penyimpanan, transformasi, dan transfer energi dipelajari. Energi disimpan sebagai energi internal (terkait dengan suhu), energi kinetik (karena gerakan), energi potensial (karena elevasi) dan energi kimia (karena komposisi kimia), berubah dari salah satu bentuk energi dan ditransfer melintasi batas baik sebagai panas atau gerak. Hukum termodinamika pertama dan kedua dirumuskan pada abad ke-19 oleh para ilmuan mengenai peningkatan efisiensi mesin uap. (Potter, 1993).

Termodinamika mempunyai penerapan praktis dalam semua cabang sains dan teknologi seperti halnya dalam berbagai aspek kehidupan sehari-hari, mulai dari urusan cuaca sampai urusan masak-memasak. Prinsip-prinsip dan hukum-hukum termodinamika digunakan pada perencanaan motor-motor bakar, pusat-pusat tenaga nuklir, pesawat-pesawat pendingin, roket, pesawat terbang, pesawat dengan tenaga listrik, dan lain-lain. (Karim, 2010)

\section{Pindah Panas}

Panas atau kalor dijelaskan sebagai bentuk energi yang dapat berpindah diantara dua sistem (atau dari sistem ke lingkungan) dengan sifat perbedaan temperatur (suhu). Menurut Saifuddin (2000), Panas adalah sebuah energi dalam keadaan transisi, dia dapat dikenali apabila melewati batas sistem sehingga dalam termodinamika panas (heat) sering disebut juga dengan transfer panas (heat transfer).

Perpindahan panas (heat transfer) merupakan ilmu untuk meramalkan perpindahan energi dalam bentuk panas yang terjadi karena adanya perbedaan suhu di antara benda atau material. Dalam proses perpindahan energi tersebut terdapat kecepatan perpindahan panas yang terjadi atau dikenal dengan laju perpindahan panas. Maka ilmu perpindahan panas juga merupakan ilmu untuk meramalkan laju perpindahan panas yang terjadi pada kondisi-kondisi tertentu. Terdapat tiga bentuk mekanisme perpindahan panas yang diketahui yaitu konduksi, konveksi, dan radiasi.

\section{Panci Bertekanan}

Panci bertekanan, atau biasa kita kenal di pasaran dengan nama "Panci Presto" merupakan sebuah alat masak yang dapat diatur tekanannya, sehingga dapat meningkatkan suhu serta titik didih suatu bahan dengan waktu tertentu. Panci tekanan memungkinkan memasak cepat dan penghematan energi dari berbagai macam makanan. Perlakuan suhu yang tinggi dan waktu yang singkat jika dikombinasikan dengan tidak adanya oksigen (kecuali pada awal 
perlakuan) juga bisa membuat nutrisi tetap terjaga. (Leelayuthsoontorn et al, 2006 dalam Flick et al, 2007).

Panci presto menghasilkan tekanan dalam ruangan tertutup sehingga menekan uap air tersebut masuk ke dalam makanan untuk menghasilkan efek transfer panas. Ketika alat presto yang ditutup rapat dan dipanaskan dalam suhu tinggi, tekanan uap air akan meningkat dan suhu akan naik. Pemasakan dengan metode presto akan terjadi dalam suhu $\pm 125{ }^{\circ} \mathrm{C}$ dan pada tekanan 5-10 psi (pada alat presto bertekenan rendah s/d sedang) atau 15 psi (pada alat presto bertekanan tinggi). Dalam kondisi tekanan tinggi, serat pada makanan akan dilunakkan dan rasa makanan akan meresap dengan cepat.

\section{METODE PENELITIAN}

\section{Alat dan Bahan}

Alat yang digunakan dalam penelitian ini adalah (1) Konsentrator surya, (2) Panci bertekanan berbahan dasar Stainless Steel dengan kapasitas total sebesar 15 liter yang telah dimodifikasi, (3) Hybrid Recorder, (4) Thermocouple tipe K, (5) Pyranometer, (6) Pressure gauge, (7) Anemometer, (8) Termometer Bola Basah dan Bola Kering, (9) Alat perbengkelan serta alat tulis sebagai alat penunjang penelitian. Bahan yang digunakan adalah fluida kerja yaitu air dan cooking oil.

\section{Variabel Penelitian}

Penelitian ini berfokus kepada uji kinerja dari sistem panci bertekanan yang merupakan salah satu komponen pada sistem konsentrator surya tipe parabola. Variabel-variabel yang akan diteliti adalah:

1. Tekanan: Pengukuran tekanan dilakukan guna mengetahui ukuran tekanan yang tepat untuk menaikkan titik didih fluida sehingga menghasilkan uap yang optimal. Pengukuran menggunakan pressure gauge.

2. Intensitas radiasi matahari: Radiasi matahari merupakan salah satu bahan yang mempengaruhi kenaikan suhu serta tekanan yang ada pada sistem. Radiasi matahari diukur menggunakan pyranometer.

3. Suhu: Pengukuran suhu dilakukan di dalam sistem, untuk mengetahui suhu optimal dari pemanasan fluida guna menghasilkan uap panas yang dibutuhkan. Pengukuran suhu dilakukan menggunakan thermocouple.

4. Massa bahan: Pengukuran massa bahan dilakukan sebagai bahan untuk mendapatkan nilai energi kalor yang diterima oleh sistem serta objek yang akan digunakan, yaitu panci, air dan minyak.

5. Kelembaban: Pengukuran kelembaban dilakukan guna membantu menentukan tekanan yang dihasilkan dari sistem panci bertekanan. Pengukuran terhadap kelembaban dilakukan menggunakan termometer bola basah dan bola kering.

6. Kecepatan angina: Pengukuran kecepatan angin dilakukan guna mengetahui adanya pengaruh aliran udara di sekitar sistem terhadap laju perpindahan panas yang terjadi pada sistem.

7. Data Perhitungan: Data perhitungan meliputi energi kalor yang diterima, energi kalor yang hilang, dan efisiensi dari sistem tersebut.

\section{Analisis Data}

Analisis data yang digunakan pada penelitian ini menggunakan analisis data kuantitatif dengan mencari hubungan dua variabel. Mencari hubungan dan membandingkan antara intensitas cahaya matahari yang diterima dengan perubahan suhu pada sistem prototipe panci bertekanan terhadap waktu. Analisis data perpindahan panas yang terjadi pada sistem panci bertekanan terhadap perubahan intensitas radiasi matahari, serta efisiensi yang dapat diraih sistem panci pada kondisi iradiasi terukur. 
1. Nilai Energi Kalor: Nilai energi kalor yang terpakai dihitung untuk masing-masing bahan yang digunakan dalam penelitian berdasarkan rumus berikut (Frank, 1996 dalam Suwito et al., 2013) :

$$
q_{\text {fluida }}=m_{\text {fluida }} \times C_{p_{\text {fluida }}} \times \Delta T_{\text {fluida }}
$$

Sedangkan untuk menghitung energi yang masuk ke dalam sistem panci digunakan persamaan sebagai berikut:

$$
q_{\text {panci }}=m_{\text {panci }} \times C p_{\text {material panci }} \times \Delta T_{\text {panci }}
$$

2. Perpindahan kalor $(q)$ : Perpindahan kalor dihitung guna mengetahui besaran kalor yang berpindah dari lingkungan ke sistem. Perpindahan kalor yang diukur yaitu perpindahan kalor secara konduksi dan perpindahan kalor secara konveksi. Perpindahan kalor secara konduksi terjadi pada saat panas dari matahari terkonsentrasi pada bidang bawah panci kemudian mengalir ke bagian dalam panci, sedangkan perpindahan kalor secara konveksi terjadi ketika aliran panas berpindah. Perpindahan kalor secara konduksi, memakai persamaan berikut:

$$
q_{k}=k \times A \times \frac{\Delta T}{x}
$$

Perhitungan perpindahan kalor secara konveksi menggunakan persamaan berikut ini:

$$
q=h A_{s}\left(T_{s}-T_{\infty}\right)
$$

3. Efisiensi Sistem: Efisiensi sistem dihitung dengan tujuan untuk mengetahui seberapa besar tingkat efisiensi sistem panci dalam menerima kalor yang berasal dari sistem konsentrator surya tipe parabola. Efisiensi pada sistem ini dihitung berdasarkan perubahan waktu selama 5 menit pengambilan data, memakai persamaan berikut,

$$
\eta_{\text {panci }}=\frac{Q_{\text {fluida }}+Q_{\text {panci }}}{\text { Iradiasi matahari yang dipantulkan }}
$$

\section{HASIL DAN PEMBAHASAN}

\section{A. Suhu dan Tekanan Optimum Sistem Panci Bertekanan}

\section{A.1. Pengukuran Suhu Sistem Panci Bertekanan}

Pengukuran suhu yang diterima sistem panci bertekanan dilakukan setiap 5 menit sekali menggunakan dua bahan yang telah ditentukan, yaitu air dan minyak sayur. Pengukuran suhu pada panci dilakukan pada 5 titik berbeda, yaitu di daerah dasar panci bagian luar dan dalam, tengah luar dan dalam, serta bagian atas atau bagian tutup panci.

Pengukuran sendiri dilakukan yaitu antara jam 10.00 sampai dengan jam 14.00 WIB menyesuaikan kondisi cuaca, karena berdasarkan penelitian awal bahwa iradiasi matahari optimal dapat diperoleh dari pukul 11.00 sampai dengan 13.00 pada kondisi cuaca cerah.

Tabel 1. Data suhu diperoleh pada sistem panci menggunakan fluida minyak sayur

\begin{tabular}{crrrrrrr}
\hline \multirow{2}{*}{ Waktu } & \multicolumn{9}{c}{ Suhu Bagian Panci (Celcius) } & Radiasi Matahari \\
\cline { 2 - 6 } & 1 & 2 & 3 & 4 & 5 & 6 & $($ W/m2) \\
\hline $10: 50$ & 30,30 & 32,60 & 30,40 & 35,80 & 32,30 & 30,90 & 1000 \\
$10: 55$ & 57,40 & 39,70 & 32,30 & 48,80 & 50,50 & 74,70 & 1010 \\
$11: 00$ & 82,40 & 53,70 & 42,90 & 54,70 & 49,10 & 115,20 & 1060 \\
$11: 05$ & 97,20 & 65,20 & 64,60 & 60,60 & 50,30 & 129,60 & 1120 \\
$11: 10$ & 112,50 & 73,30 & 79,80 & 63,80 & 51,90 & 143,10 & 1050 \\
$11: 15$ & 123,00 & 78,20 & 93,00 & 65,30 & 52,10 & 151,60 & 1070 \\
$11: 20$ & 136,10 & 89,70 & 107,80 & 71,60 & 72,10 & 176,70 & 1050 \\
$11: 25$ & 147,80 & 93,10 & 120,40 & 77,00 & 62,50 & 178,30 & 1050 \\
$11: 30$ & 155,10 & 97,60 & 129,30 & 75,80 & 69,10 & 187,50 & 990
\end{tabular}




\begin{tabular}{rrrrrrrl}
$11: 35$ & 167,30 & 107,10 & 141,10 & 81,90 & 74,40 & 202,70 & 1050 \\
$11: 40$ & 172,90 & 110,20 & 149,50 & 82,90 & 67,30 & 197,80 & 1070 \\
$11: 45$ & 179,20 & 113,20 & 157,70 & 86,30 & 68,20 & 202,10 & 1080 \\
$11: 50$ & 186,20 & 114,20 & 164,70 & 90,40 & 75,50 & 205,00 & 1000 \\
$11: 55$ & 193,90 & 117,10 & 172,20 & 92,70 & 69,70 & 213,30 & 1060 \\
$12: 00$ & 202,10 & 125,90 & 180,60 & 97,80 & 80,40 & 224,20 & 1080 \\
$12: 05$ & 179,90 & 128,40 & 183,00 & 93,10 & 66,50 & 162,40 & 200 \\
$12: 10$ & 181,30 & 121,20 & 176,90 & 96,40 & 70,30 & 191,40 & 1120 \\
$12: 15$ & 198,30 & 126,30 & 180,00 & 96,60 & 73,50 & 205,30 & 1150 \\
$12: 20$ & 202,50 & 131,20 & 185,40 & 97,60 & 84,70 & 204,90 & 1180 \\
$12: 25$ & 200,10 & 130,50 & 189,50 & 98,20 & 67,80 & 185,90 & 320 \\
$12: 30$ & 171,00 & 116,90 & 184,40 & 93,50 & 58,50 & 155,50 & 200 \\
$12: 35$ & 158,10 & 111,10 & 176,90 & 89,40 & 62,50 & 144,70 & 210 \\
$12: 40$ & 147,40 & 107,10 & 169,40 & 84,10 & 55,00 & 133,90 & 200 \\
$12: 45$ & 139,90 & 103,10 & 161,70 & 80,80 & 52,00 & 125,40 & 200 \\
$12: 50$ & 134,40 & 98,60 & 155,90 & 79,80 & 52,20 & 124,10 & 170 \\
$12: 55$ & 126,80 & 94,60 & 149,00 & 73,80 & 50,30 & 112,70 & 210 \\
$13: 00$ & 155,10 & 96,40 & 145,80 & 78,90 & 60,80 & 173,90 & 990 \\
$13: 05$ & 165,20 & 106,30 & 150,30 & 79,70 & 61,30 & 153,60 & 670 \\
$13: 10$ & 164,60 & 108,60 & 155,20 & 84,60 & 66,10 & 147,60 & 200 \\
$13: 15$ & 140,40 & 96,10 & 151,80 & 76,70 & 52,20 & 126,40 & 210 \\
$13: 20$ & 171,00 & 105,30 & 152,10 & 84,50 & 58,20 & 184,10 & 940 \\
$13: 25$ & 177,10 & 112,50 & 158,10 & 89,70 & 69,60 & 185,40 & 900 \\
$13: 30$ & 176,80 & 111,90 & 160,60 & 90,00 & 72,60 & 186,70 & 920 \\
\hline
\end{tabular}

Terlihat pada Tabel 1, terjadi penurunan suhu pada pukul 12.05 WIB. Ini disebabkan karena adanya pengurangan intensitas radiasi matahari sampai dengan $200 \mathrm{~W}$ hingga 5 menit berikutnya atau sampai pukul 12.10 WIB. Penurunan nilai intensitas radiasi matahari pada pukul 12.05 WIB dikarenakan matahari sempat tertutupi oleh awan, sehingga iradiasi yang diterima oleh pyranometer tidak optimal. Intensitas radiasi matahari tertinggi diperoleh pada pukul 12.20 WIB dengan nilai intensitas radiasi matahari sebesar $1180 \mathrm{~W} / \mathrm{m}^{2}$, berdampak pada kenaikan suhu sampai titik optimum pada setiap titik pengukuran. Lebih jelasnya bisa dilihat pada Gambar 1. 


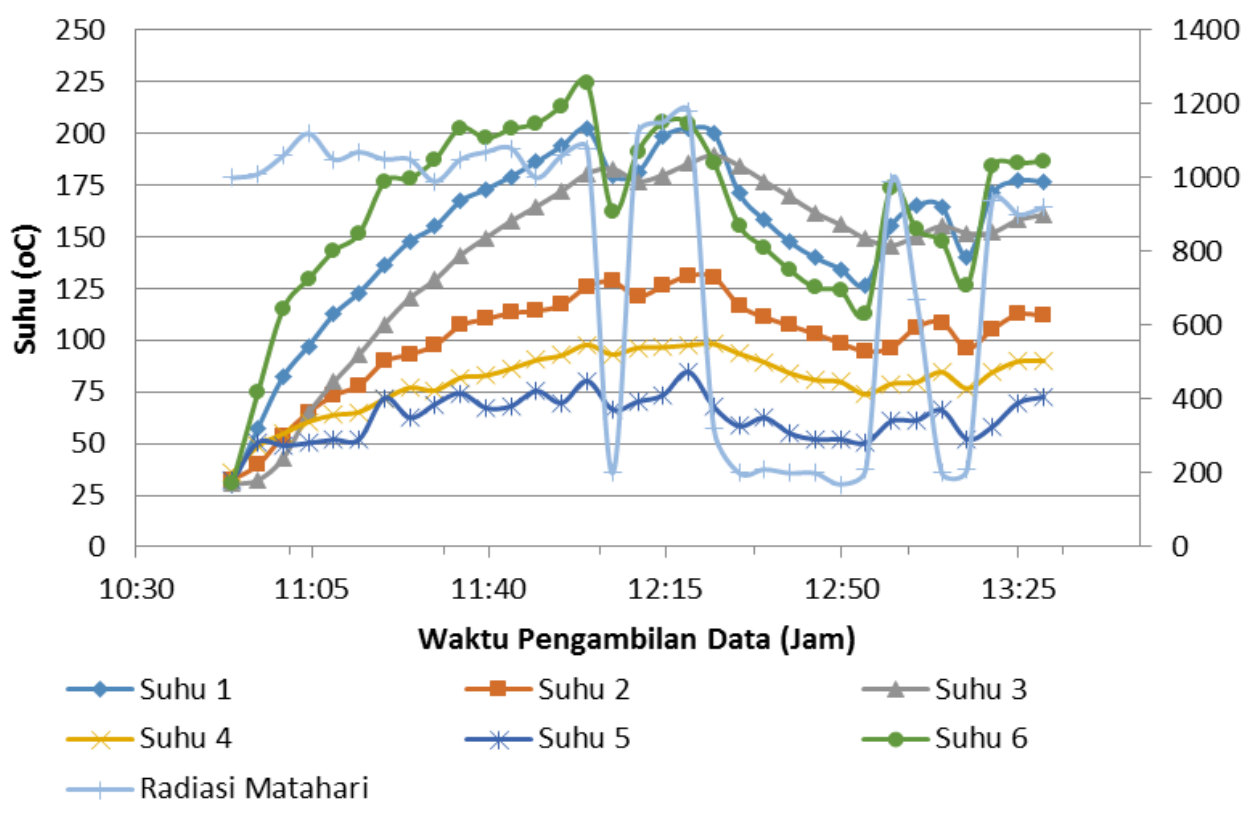

Gambar 1. Hubungan waktu dan intensitas radiasi matahari terhadap perolehan suhu sistem panci menggunakan fluida kerja minyak sayur.

Gambar 1 menunjukkan bahwa pada titik 6, yaitu bagian dasar luar panci mengalami kenaikan suhu tertinggi dibandingkan 4 titik pengukuran lainnya pada sistem panci, yaitu mencapai suhu $224,2^{\circ} \mathrm{C}$, setelah itu pula mengalami penurunan hingga mencapai suhu sebesar $162,4^{\circ} \mathrm{C}$. Dibandingkan dengan sisi dalam bagian dasar panci yang mengalami penurunan dari suhu $202,10{ }^{\circ} \mathrm{C}$ menjadi $179,9{ }^{\circ} \mathrm{C}$, sisi luar bagian dasar panci dipengaruhi oleh kondisi lingkungan sekitar, sehingga ketika iradiasi turun (mencapai $200 \mathrm{~W} / \mathrm{m}^{2}$ ) mengakibatkan suhu di bagian ini mengalami penurunan drastis sebesar $61,8{ }^{\circ} \mathrm{C}$. Pada bagian lain panci suhu optimum yang dicapai adalah sebagai berikut: bagian dasar-dalam panci $=202,5{ }^{\circ} \mathrm{C}$, bagian dindingdalam panci $=131,2^{\circ} \mathrm{C}$, bagian tutup panci $=98,2^{\circ} \mathrm{C}$, dan dinding-luar panci $=84,7^{\circ} \mathrm{C}$.

Tabel 2. Data suhu diperoleh pada sistem panci menggunakan fluida air

\begin{tabular}{|c|c|c|c|c|c|c|c|}
\hline \multirow{2}{*}{ Waktu } & \multicolumn{6}{|c|}{ Suhu Bagian Panci } & \multirow{2}{*}{$\begin{array}{c}\text { Iradiasi Matahari } \\
\left(\mathrm{W} / \mathrm{m}^{2}\right)\end{array}$} \\
\hline & 1 & 2 & 3 & 4 & 5 & 6 & \\
\hline $10: 00$ & 38,60 & 37,50 & 29,00 & 46,60 & 45,60 & 70,50 & 790 \\
\hline 10:05 & 46,50 & 46,80 & 36,50 & 52,60 & 48,00 & 85,30 & 790 \\
\hline $10: 10$ & 52,90 & 52,00 & 43,90 & 55,80 & 46,00 & 92,90 & 800 \\
\hline $10: 15$ & 59,00 & 56,30 & 50,60 & 59,10 & 57,50 & 98,70 & 780 \\
\hline $10: 20$ & 62,30 & 58,90 & 54,80 & 61,30 & 54,30 & 101,90 & 830 \\
\hline $10: 25$ & 70,40 & 64,50 & 61,50 & 63,80 & 59,80 & 104,80 & 850 \\
\hline $10: 30$ & 73,70 & 67,70 & 66,90 & 64,30 & 56,60 & 102,40 & 820 \\
\hline $10: 35$ & 71,30 & 66,60 & 69,10 & 66,50 & 52,40 & 87,10 & 850 \\
\hline $10: 40$ & 80,40 & 72,70 & 74,00 & 71,80 & 63,90 & 109,00 & 890 \\
\hline $10: 45$ & 82,30 & 74,30 & 76,50 & 70,40 & 58,30 & 104,00 & 800 \\
\hline $10: 50$ & 89,30 & 79,30 & 81,10 & 76,10 & 65,20 & 126,40 & 880 \\
\hline $10: 55$ & 94,90 & 84,30 & 86,00 & 81,00 & 71,30 & 129,90 & 900 \\
\hline $11: 00$ & 100,10 & 89,40 & 90,90 & 85,80 & 67,60 & 143,80 & 910 \\
\hline
\end{tabular}


JABER 2(1): 68-85 (2021)

Analisis Kinerja Sistem Panci Bertekanan - Ropiudin et al

\begin{tabular}{|c|c|c|c|c|c|c|c|}
\hline \multirow{2}{*}{ Waktu } & \multicolumn{6}{|c|}{ Suhu Bagian Panci } & \multirow{2}{*}{$\begin{array}{c}\text { Iradiasi Matahari } \\
\left(\mathrm{W} / \mathrm{m}^{2}\right)\end{array}$} \\
\hline & 1 & 2 & 3 & 4 & 5 & 6 & \\
\hline 11:05 & 101,00 & 93,80 & 96,30 & 89,00 & 70,60 & 136,90 & 980 \\
\hline $11: 10$ & 102,00 & 99,50 & 101,20 & 92,10 & 77,60 & 134,40 & 940 \\
\hline $11: 15$ & 103,40 & 102,40 & 103,30 & 97,00 & 70,90 & 146,20 & 1010 \\
\hline $11: 20$ & 103,60 & 103,30 & 103,60 & 95,30 & 75,50 & 132,80 & 300 \\
\hline $11: 25$ & 95,30 & 96,70 & 98,70 & 86,40 & 57,80 & 92,10 & 180 \\
\hline $11: 30$ & 91,80 & 93,80 & 96,20 & 83,40 & 54,70 & 89,30 & 210 \\
\hline $11: 35$ & 88,00 & 84,50 & 92,70 & 77,00 & 50,50 & 84,20 & 120 \\
\hline $11: 40$ & 82,40 & 84,80 & 88,50 & 73,70 & 48,30 & 79,80 & 130 \\
\hline $11: 45$ & 80,50 & 81,70 & 85,70 & 71,80 & 47,40 & 77,90 & 110 \\
\hline $11: 50$ & 82,20 & 80,20 & 84,00 & 71,20 & 48,40 & 79,40 & 110 \\
\hline $11: 55$ & 80,10 & 77,80 & 82,30 & 68,10 & 47,00 & 77,20 & 120 \\
\hline $12: 00$ & 79,20 & 75,30 & 81,20 & 67,10 & 44,80 & 75,10 & 180 \\
\hline $12: 05$ & 79,00 & 74,30 & 80,80 & 65,20 & 44,30 & 72,20 & 130 \\
\hline $12: 10$ & 78,60 & 73,20 & 81,20 & 65,20 & 43,20 & 71,20 & 120 \\
\hline $12: 15$ & 77,20 & 73,20 & 80,60 & 63,40 & 42,10 & 70,90 & 110 \\
\hline $12: 20$ & 76,00 & 73,20 & 79,60 & 62,10 & 41,20 & 69,60 & 130 \\
\hline $12: 25$ & 74,90 & 73,10 & 78,20 & 60,10 & 40,80 & 68,60 & 140 \\
\hline $12: 30$ & 73,80 & 72,50 & 77,80 & 59,20 & 40,50 & 67,90 & 120 \\
\hline $12: 35$ & 72,80 & 71,60 & 75,40 & 58,70 & 38,10 & 66,60 & 110 \\
\hline $12: 40$ & 71,10 & 68,20 & 73,20 & 57,50 & 37,20 & 64,30 & 120 \\
\hline $12: 45$ & 69,30 & 65,20 & 71,20 & 56,10 & 36,10 & 62,90 & 130 \\
\hline $12: 50$ & 67,50 & 62,10 & 68,70 & 55,40 & 35,10 & 60,10 & 140 \\
\hline $12: 55$ & 66,50 & 60,20 & 67,10 & 54,30 & 36,20 & 61,20 & 140 \\
\hline $13: 00$ & 64,10 & 59,30 & 66,10 & 52,30 & 34,30 & 60,20 & 120 \\
\hline $13: 05$ & 63,20 & 57,30 & 65,10 & 51,30 & 33,20 & 60,30 & 110 \\
\hline $13: 10$ & 62,20 & 56,20 & 63,10 & 52,10 & 31,20 & 58,10 & 130 \\
\hline $13: 15$ & 61,80 & 55,30 & 62,50 & 51,50 & 32,20 & 57,10 & 210 \\
\hline $13: 20$ & 60,80 & 54,30 & 59,80 & 50,20 & 31,20 & 56,10 & 230 \\
\hline $13: 25$ & 59,20 & 52,30 & 57,30 & 48,20 & 31,00 & 54,20 & 220 \\
\hline $13: 30$ & 58,60 & 52,00 & 56,80 & 47,90 & 30,20 & 54,00 & 210 \\
\hline $13: 35$ & 57,60 & 51,90 & 56,50 & 47,20 & 29,80 & 54,30 & 230 \\
\hline $13: 40$ & 57,20 & 51,67 & 55,50 & 46,80 & 29,70 & 54,00 & 130 \\
\hline $13: 45$ & 56,80 & 51,47 & 55,10 & 46,30 & 29,10 & 54,05 & 110 \\
\hline $13: 50$ & 56,40 & 51,27 & 54,53 & 45,81 & 28,67 & 54,02 & 110 \\
\hline $13: 55$ & 56,00 & 51,07 & 53,96 & 45,32 & 28,24 & 53,99 & 110 \\
\hline $14: 00$ & 55,60 & 50,87 & 53,39 & 44,83 & 27,81 & 53,96 & 110 \\
\hline
\end{tabular}

Berdasarkan data pada Tabel 2, iradiasi optimal tercapai pada pukul 11.15 WIB. Dengan kondisi cuaca cerah. Sedangkan lewat dari pukul 11.15 terjadi penurunan nilai iradiasi matahari, dikarenakan perubahan cuaca menjadi berawan. Suhu optimum dari masing-masing bagian panci yang diukur adalah sebagai berikut: titik 1 (dasar-dalam panci) $=103,6{ }^{\circ} \mathrm{C}$, titik 2 (dinding-dalam panci) $=103,3{ }^{\circ} \mathrm{C}$, titik 4 (tutup panci) $=97{ }^{\circ} \mathrm{C}$, titik 5 (dinding luar panci) $=$ $77,6^{\circ} \mathrm{C}$, dan titik 6 (dasar-luar panci) $=146,2{ }^{\circ} \mathrm{C}$. 


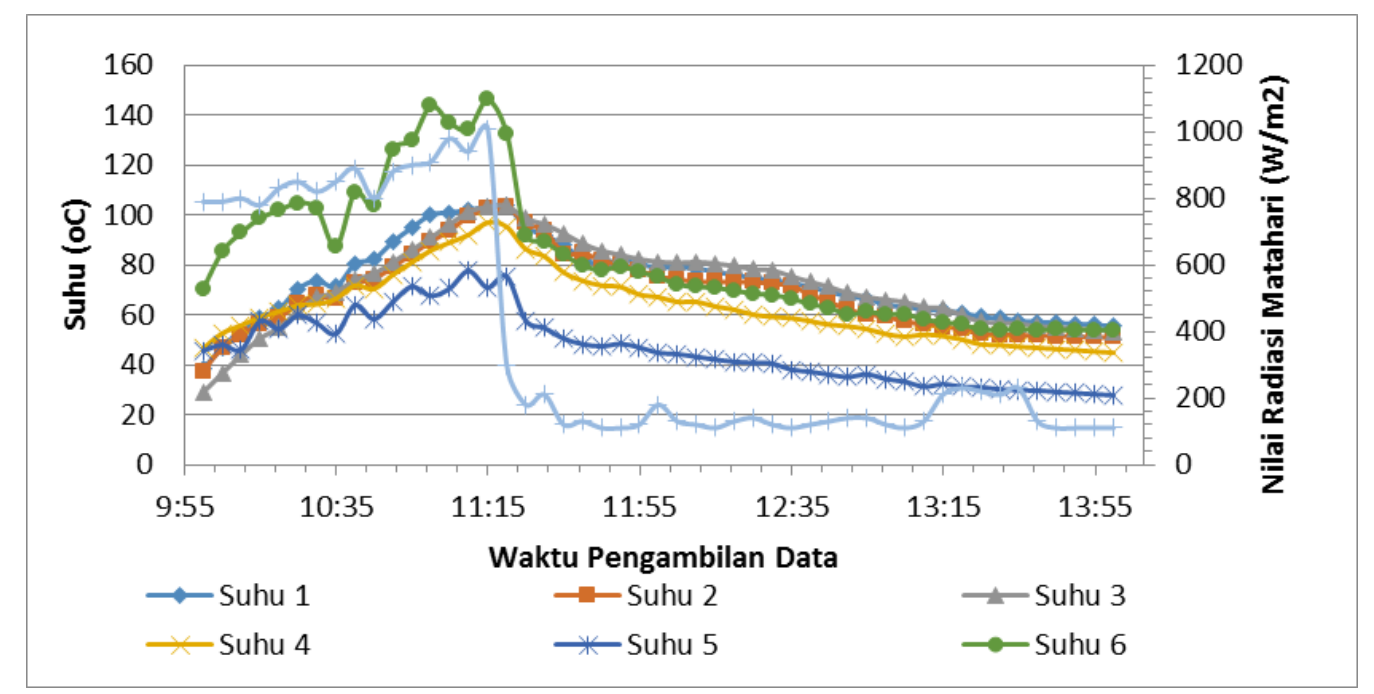

Gambar 2. Hubungan waktu dan intensitas radiasi matahari terhadap perolehan suhu sistem panci memakai fluida kerja air.

Gambar 2 menunjukkan suhu pada titik 6 merupakan yang paling tinggi dibandingkan dengan suhu di titik pengukuran lainnya. Hal ini disebabkan karena titik 6 merupakan titik pengukuran di dasar panci, sehingga iradiasi yang terkonsentrasi dari reflektor parabola langsung menuju bidang bawah luar panci. Sama halnya dengan data suhu ketika menggunakan minyak sayur, bagian ini mengalami penurunan drastis sebesar $40,7{ }^{\circ} \mathrm{C}$ pada kondisi iradiasi matahari dari pukul 11.20 - 11.25 WIB, menurun hingga mencapai tingkat iradiasi sebesar 180 $\mathrm{W} / \mathrm{m}^{2}$.

Terlihat dari kedua data yang disajikan, pada bagian dinding luar panci merupakan bagian yang bersuhu terendah dibandingkan dengan titik lain di dalam sistem. Ini disebabkan karena adanya isolasi oleh glasswool guna menahan panas dari lingkungan masuk ke dalam sistem melalui dinding luar panci. Tabel 1 dan Tabel 2 menunjukkan pada waktu tertentu, terjadi penurunan suhu yang cukup besar di titik 6 yang merupakan bagian dasar luar panci. Hal ini disebabkan karena pada titik tersebut merupakan titik yang berhubungan langsung dengan iradiasi yang dipantulkan oleh konsentrator surya, sehingga, ketika iradiasi menurun, membuat iradiasi yang terpantulkan menjadi sedikit.

Faktor lainnya yang mempengaruhi hal tersebut antara lain dari bahan material pada dasar panci presto yang diberi campuran aluminium. Hal ini dilakukan mengingat stainless steel sebagai bahan penyusun panci presto merupakan konduktor yang buruk, sehingga untuk mendapatkan panas yang optimum diperlukan tambahan lapisan yang membuat bagian dasar menjadi cepat menerima panas serta memperoleh hasil pemasakan yang maksimal. (www.gopresto.com).

Namun, akibat lain yang ditimbulkan dengan adanya lapisan aluminium tersebut membuat bagian dasar panci mudah melepaskan panas. Bahan aluminium merupakan konduktor panas yang baik (nilai konduktivitas $=256 \mathrm{~W} / \mathrm{m} . \mathrm{K}$ ) dapat cepat melepaskan panas dari sistem ke lingkungan ketika suhu di lingkungan lebih rendah dibandingkan suhu di dalam sistem.

\section{A.2. Pengukuran Tekanan Sistem Panci Bertekanan}

Pengukuran tekanan yang dihasilkan dari proses termal di dalam panci dilakukan setiap 5 kali dalam kurun waktu selama 5 hari. Pengukuran dilakukan di bagian dalam panci bertekanan untuk mengetahui kemampuan panci yang dipakai apakah berhasil menghasilkan tekanan atau tidak. Menurut Saifuddin (2000), ketika kerapatan uap di suatu ruangan tertutup bertambah, maka akan terjadi suatu tumbukan-tumbukan diakibatkan gerakan cepat oleh molekul-molekul uap tadi yang menyebabkan tekanan di dalam ruang naik. Ketika tekanan naik, maka titik didihnya pun semakin meningkat. 
Berdasarkan data pada Tabel 1, tidak terjadi kenaikan tekanan. Ini disebabkan karena titik didih minyak sangat tinggi yaitu mencapai $280{ }^{\circ} \mathrm{C}$, sehingga tidak menimbulkan uap panas yang dapat menyebabkan timbulnya kenaikan tekanan di dalam sistem. Sedangkan pada percobaan menggunakan air, tekanan naik sebesar 0,15 bar setelah melebihi titik didih standar, yaitu mencapai $103,6{ }^{\circ} \mathrm{C}$.

\section{B. Analisis Pindah Panas pada Sistem Panci Bertekanan}

Perhitungan pindah panas dilakukan guna mengetahui kemampuan sistem panci bertekanan dalam menerima panas dari reflektor parabola, dan kemampuan untuk mempertahankan panas yang telah diterima di dalam sistem. Susanto (2012) menuturkan, semakin tinggi nilai konduktivitas suatu material maka semakin baik mentransfer panas sehingga semakin cepat melepaskan panas begitu juga sebaliknya. Perhitungan dilakukan berdasarkan data yang diukur lima menit sekali. Perhitungan pindah panas yang terjadi pada sistem panci terdiri dari laju perpindahan panas secara konduksi pada sistem panci, serta tingkat energi kalor yang diterima juga yang dilepaskan setiap waktu pengukuran. Perhitungan tingkat energi kalor yang diterima sistem menggunakan persamaan sebagai berikut,

$$
Q=(m \times C p \times \Delta T)+\left(\frac{k}{x} \times A \times \Delta T\right)
$$

Nilai Q merupakan kalor total yang diterima oleh titik pada sistem panci berdasarkan perbedaan suhu awal ditambah dengan adanya peristiwa perpindahan panas secara konduksi dan nilai kalor yang diterima dari proses konveksi, dengan satuan yang dihasilkan adalah kW.

Data Tabel 1 digunakan untuk menghitung nilai kalor yang diterima ataupun dilepaskan oleh sistem, dan dihasilkan seperti pada Tabel 3 berikut:

Tabel 3. Nilai kalor pada panci menggunakan fluida kerja minyak sayur

\begin{tabular}{|c|c|c|c|c|c|}
\hline \multirow{2}{*}{ Waktu } & \multicolumn{4}{|c|}{ Nilai Kalor yang Diterima (kW) } & \multirow{2}{*}{ Radiasi $\left(\mathrm{W} / \mathrm{m}^{2}\right)$} \\
\hline & $\mathrm{Q}_{1}$ & $\mathrm{Q}_{2}$ & $\mathrm{Q}_{3}$ & $\mathrm{Q}_{4}$ & \\
\hline $10: 50$ & 3,09 & $-0,01$ & $-0,31$ & 1,52 & 1000 \\
\hline $10: 55$ & 88,25 & 3,53 & $-1,04$ & $-54,69$ & 1010 \\
\hline $11: 00$ & 167,28 & 5,56 & $-1,52$ & 23,30 & 1060 \\
\hline 11:05 & 165,45 & 4,59 & $-0,08$ & 75,46 & 1120 \\
\hline $11: 10$ & 156,51 & 4,60 & 0,91 & 108,37 & 1050 \\
\hline $11: 15$ & 146,50 & 4,22 & 2,08 & 132,18 & 1070 \\
\hline $11: 20$ & 207,60 & 3,98 & 2,55 & 89,13 & 1050 \\
\hline $11: 25$ & 156,48 & 3,86 & 3,84 & 154,96 & 1050 \\
\hline $11: 30$ & 166,22 & 3,63 & 4,46 & 144,33 & 990 \\
\hline $11: 35$ & 181,62 & 3,69 & 4,79 & 165,60 & 1050 \\
\hline $11: 40$ & 128,38 & 3,29 & 5,53 & 217,25 & 1070 \\
\hline $11: 45$ & 118,30 & 3,03 & 6,26 & 227,89 & 1080 \\
\hline $11: 50$ & 97,58 & 3,03 & 7,11 & 195,98 & 1000 \\
\hline $11: 55$ & 100,73 & 3,05 & 7,76 & 240,04 & 1060 \\
\hline $12: 00$ & 114,55 & 3,03 & 7,70 & 230,42 & 1080 \\
\hline $12: 05$ & $-86,82$ & $-0,44$ & 7,69 & 313,47 & 200 \\
\hline $12: 10$ & 53,34 & 0,62 & 7,84 & 257,77 & 1120 \\
\hline $12: 15$ & 37,83 & 2,58 & 7,56 & 267,39 & 1150 \\
\hline $12: 20$ & 14,53 & 2,41 & 7,63 & 235,48 & 1180 \\
\hline
\end{tabular}




\begin{tabular}{|c|c|c|c|c|c|}
\hline \multirow{2}{*}{ Waktu } & \multicolumn{4}{|c|}{ Nilai Kalor yang Diterima (kW) } & \multirow{2}{*}{ Radiasi $\left(\mathrm{W} / \mathrm{m}^{2}\right)$} \\
\hline & $\mathrm{Q}_{1}$ & $\mathrm{Q}_{2}$ & $\mathrm{Q}_{3}$ & $\mathrm{Q}_{4}$ & \\
\hline $12: 25$ & $-69,79$ & 1,49 & 8,30 & 317,52 & 320 \\
\hline $12: 30$ & $-76,78$ & $-1,89$ & 9,50 & 295,75 & 200 \\
\hline $12: 35$ & $-66,29$ & $-2,65$ & 9,26 & 246,12 & 210 \\
\hline $12: 40$ & $-66,94$ & $-3,10$ & 8,77 & 263,84 & 200 \\
\hline $12: 45$ & $-72,12$ & $-3,07$ & 8,25 & 258,78 & 200 \\
\hline $12: 50$ & $-50,87$ & $-3,03$ & 8,07 & 234,98 & 170 \\
\hline $12: 55$ & $-70,26$ & $-3,12$ & 7,66 & 224,34 & 210 \\
\hline 13:00 & 97,17 & 1,31 & 6,95 & 180,29 & 990 \\
\hline 13:05 & $-57,06$ & 2,10 & 6,19 & 227,89 & 670 \\
\hline $13: 10$ & $-84,48$ & 1,32 & 6,56 & 215,23 & 200 \\
\hline 13:15 & $-69,57$ & $-1,60$ & 7,84 & 222,32 & 210 \\
\hline $13: 20$ & 68,44 & 2,66 & 6,59 & 238,52 & 940 \\
\hline $13: 25$ & 44,14 & 2,67 & 6,42 & 217,25 & 900 \\
\hline $13: 30$ & 52,26 & 2,28 & 6,85 & 199,02 & 920 \\
\hline
\end{tabular}

Keterangan :

$\mathrm{Q}_{1}=$ Kalor yang diterima titik 1 (dasar-dalam)

$\mathrm{Q}_{2}=$ Kalor yang diterima dari titik 1 ke fluida (titik 3)

$\mathrm{Q}_{3}=$ Kalor yang diterima dari fluida ke dinding dalam (titik 5)

$\mathrm{Q}_{4}=$ Kalor yang diterima dari dinding dalam (titik 2) ke dinding luar (titik 5)

Tabel 3 menunjukkan, kalor optimum yang diterima sistem di setiap titik yaitu: $\mathrm{Q}_{1}$ sebesar 207,60 kW pada pukul 11.20 pada kondisi iradiasi matahari terukur sebesar $1050 \mathrm{~W}$, $\mathrm{Q}_{2}$ sebesar 5,56 $\mathrm{kW}$ pada pukul 11.00 dengan iradiasi matahari terukur sebesar $1060 \mathrm{~W}, \mathrm{Q}_{3}$ sebesar 9,50 kW pada pukul 12.30 dengan iradiasi matahari terukur sebesar $200 \mathrm{~W}$ dan $\mathrm{Q}_{4}$ sebesar -54,69 kW pada pukul 10.55 dengan iradiasi matahari terukur sebesar $1010 \mathrm{~W}$. Pada $\mathrm{Q}_{1}$, panas didapatkan dari perpindahan secara konduksi dari sisi luar, sedangkan untuk Q4, terjadi perpindahan panas dari sisi dalam ke sisi luar dari sistem, oleh karena itu nilai yang diperoleh pada Q4 adalah negatif, karena terjadi perpindahan panas dari sisi luar ke sisi dalam.

Pelepasan panas yang cukup besar dari sistem ke lingkungan, terjadi pada $\mathrm{Q}_{1}$ yang melepaskan kalor sebesar $-84,48 \mathrm{~kW}$ pada pukul 13.10, saat kondisi iradiasi matahari sebesar $200 \mathrm{~W} / \mathrm{m}^{2}$, dan $\mathrm{Q}_{4}=317,52 \mathrm{~kW}$ pada pukul 12.25 kondisi iradiasi matahari sebesar $320 \mathrm{~W} / \mathrm{m}^{2}$. Hal ini dapat terjadi disebabkan oleh adanya pengaruh lingkungan seperti perubahan nilai iradiasi matahari yang cukup drastis, dan mengakibatkan proses perpindahan panas secara konduksi berubah arah. Suhu lingkungan yang lebih rendah dibandingkan suhu sistem menyebabkan panas pada sistem berpindah menuju lingkungan. Pada $\mathrm{Q}_{2}$ terjadi perpindahan panas dari stainless steel ke fluida dan sebaliknya pada $\mathrm{Q}_{3}$ (fluida $\rightarrow$ dinding panci stainless steel), sedangkan pada $\mathrm{Q}_{4}$ panas dialirkan menuju dinding luar. Terlihat dari Tabel 4, bahwa pada $\mathrm{Q}_{4}$ terjadi perpindahan panas dari dinding dalam ke dinding luar yang cukup besar. Hal ini disebabkan dari masih adanya perpindahan panas dari lingkungan menuju dinding bagian luar. Dimungkinkan bahwa dari glasswool yang dipasangkan terlalu tipis, sehingga panas dari lingkungan dapat mempengaruhi laju perpindahan panas pada sistem.

Perhitungan kalor yang diterima oleh sistem juga dilakukan ketika menggunakan fluida kerja air, dan nilai kalor yang diterima/dilepaskan dijelaskan pada Tabel 4 berikut.

Tabel 4. Nilai kalor pada panci menggunakan fluida kerja air

\begin{tabular}{cccccc}
\hline \multirow{2}{*}{ Waktu } & \multicolumn{4}{c}{ Nilai Kalor yang Diperoleh $(\mathrm{kW})$} & \multirow{2}{*}{ Iradiasi $\left(\mathrm{W} / \mathrm{m}^{2}\right)$} \\
\cline { 2 - 5 } & $\mathrm{Q}_{1}$ & $\mathrm{Q}_{2}$ & $\mathrm{Q}_{3}$ & $\mathrm{Q}_{4}$ & \\
\hline $10: 00$ & 161,66 & 8,09 & $-15,80$ & $-41,01$ & 790
\end{tabular}




\begin{tabular}{|c|c|c|c|c|c|}
\hline \multirow{2}{*}{ Waktu } & \multicolumn{4}{|c|}{ Nilai Kalor yang Diperoleh (kW) } & \multirow{2}{*}{ Iradiasi $\left(\mathrm{W} / \mathrm{m}^{2}\right)$} \\
\hline & $\mathrm{Q}_{1}$ & $\mathrm{Q}_{2}$ & $\mathrm{Q}_{3}$ & $\mathrm{Q}_{4}$ & \\
\hline $10: 05$ & 196,80 & 9,80 & $-10,94$ & $-6,08$ & 790 \\
\hline $10: 10$ & 202,97 & 7,71 & $-2,00$ & 30,38 & 800 \\
\hline $10: 15$ & 201,53 & 5,42 & $-6,57$ & $-6,08$ & 780 \\
\hline $10: 20$ & 201,07 & 3,90 & 0,48 & 23,29 & 830 \\
\hline $10: 25$ & 174,78 & 2,85 & 1,62 & 23,80 & 850 \\
\hline $10: 30$ & 145,88 & 0,76 & 9,80 & 56,20 & 820 \\
\hline $10: 35$ & 80,36 & $-2,38$ & 15,89 & 71,90 & 850 \\
\hline $10: 40$ & 145,47 & $-1,24$ & 9,61 & 44,56 & 890 \\
\hline $10: 45$ & 110,46 & $-2,09$ & 17,32 & 81,01 & 800 \\
\hline $10: 50$ & 188,74 & $-1,71$ & 15,13 & 71,39 & 880 \\
\hline $10: 55$ & 178,15 & $-1,62$ & 13,99 & 65,82 & 900 \\
\hline $11: 00$ & 222,39 & $-1,43$ & 22,17 & 110,38 & 910 \\
\hline $11: 05$ & 182,80 & $-2,38$ & 24,46 & 117,47 & 980 \\
\hline $11: 10$ & 165,05 & $-1,62$ & 22,46 & 110,89 & 940 \\
\hline $11: 15$ & 217,86 & $-0,86$ & 30,83 & 159,50 & 1010 \\
\hline $11: 20$ & 148,82 & $-0,29$ & 26,74 & 140,76 & 300 \\
\hline $11: 25$ & $-15,77$ & $-1,90$ & 38,92 & 196,97 & 180 \\
\hline $11: 30$ & $-12,27$ & $-2,28$ & 39,49 & 197,98 & 210 \\
\hline $11: 35$ & $-18,92$ & $-7,80$ & 40,16 & 172,16 & 120 \\
\hline $11: 40$ & $-12,90$ & $-3,52$ & 38,26 & 184,81 & 130 \\
\hline $11: 45$ & $-12,93$ & $-3,81$ & 36,45 & 173,67 & 110 \\
\hline $11: 50$ & $-13,92$ & $-3,62$ & 33,88 & 161,02 & 110 \\
\hline 11:55 & $-14,45$ & $-4,28$ & 33,59 & 155,95 & 120 \\
\hline $12: 00$ & $-20,56$ & $-5,61$ & 34,64 & 154,43 & 180 \\
\hline $12: 05$ & $-34,27$ & $-6,19$ & 34,73 & 151,90 & 130 \\
\hline $12: 10$ & $-37,32$ & $-7,61$ & 36,16 & 151,90 & 120 \\
\hline $12: 15$ & $-31,75$ & $-7,04$ & 36,64 & 157,47 & 110 \\
\hline $12: 20$ & $-32,28$ & $-6,09$ & 36,54 & 162,03 & 130 \\
\hline $12: 25$ & $-31,78$ & $-4,85$ & 35,59 & 163,55 & 140 \\
\hline $12: 30$ & $-29,77$ & $-5,04$ & 35,50 & 162,03 & 120 \\
\hline $12: 35$ & $-31,31$ & $-3,62$ & 35,50 & 169,62 & 110 \\
\hline $12: 40$ & $-34,37$ & $-4,76$ & 34,26 & 156,97 & 120 \\
\hline $12: 45$ & $-32,37$ & $-5,71$ & 33,40 & 147,34 & 130 \\
\hline $12: 50$ & $-37,47$ & $-6,28$ & 31,97 & 136,71 & 140 \\
\hline $12: 55$ & $-26,82$ & $-6,57$ & 29,41 & 121,52 & 140 \\
\hline $13: 00$ & $-19,74$ & $-6,47$ & 30,26 & 126,59 & 120 \\
\hline $13: 05$ & $-14,68$ & $-7,42$ & 30,36 & 122,03 & 110 \\
\hline $13: 10$ & $-20,79$ & $-6,57$ & 30,36 & 126,59 & 130 \\
\hline $13: 15$ & $-23,84$ & $-6,85$ & 28,83 & 116,96 & 210 \\
\hline $13: 20$ & $-23,85$ & $-5,23$ & 27,22 & 116,96 & 230 \\
\hline $13: 25$ & $-25,39$ & $-4,76$ & 25,03 & 107,85 & 220 \\
\hline $13: 30$ & $-23,37$ & $-4,57$ & 25,31 & 110,38 & 210 \\
\hline
\end{tabular}




\begin{tabular}{|c|c|c|c|c|c|}
\hline \multirow{2}{*}{ Waktu } & \multicolumn{4}{|c|}{ Nilai Kalor yang Diperoleh (kW) } & \multirow{2}{*}{ Iradiasi $\left(\mathrm{W} / \mathrm{m}^{2}\right)$} \\
\hline & $\mathrm{Q}_{1}$ & $\mathrm{Q}_{2}$ & $\mathrm{Q}_{3}$ & $\mathrm{Q}_{4}$ & \\
\hline $13: 35$ & $-16,79$ & $-4,38$ & 25,41 & 111,90 & 230 \\
\hline $13: 40$ & $-16,28$ & $-3,65$ & 24,55 & 111,23 & 130 \\
\hline $13: 45$ & $-14,00$ & $-3,46$ & 24,74 & 113,25 & 110 \\
\hline $13: 50$ & $-12,13$ & $-3,11$ & 24,61 & 114,42 & 110 \\
\hline $13: 55$ & $-10,26$ & $-2,75$ & 24,48 & 115,58 & 110 \\
\hline $14: 00$ & $-8,38$ & $-2,40$ & 24,34 & 116,75 & 110 \\
\hline
\end{tabular}

Sama halnya data di Tabel 3, data hasil perhitungan yang tergambar pada Tabel 4 pula menunjukkan adanya penerimaan kalor optimum dan pelepasan kalor yang cukup besar terjadi pada sistem. Kalor optimum yang diterima pada $\mathrm{Q}_{1}$ sebesar 222,39 $\mathrm{kW}$ pada pukul 11.00, dengan kondisi iradiasi matahari terukur sebesar $910 \mathrm{~W} / \mathrm{m}^{2}$, dan $\mathrm{Q}_{4}=-41,01 \mathrm{~kW}$ pada kondisi iradiasi surya sebesar $210 \mathrm{~W} / \mathrm{m}^{2} . \mathrm{Q}_{2}$ dan $\mathrm{Q}_{3}$ merupakan perpindahan panas dari permukaan dasar dalam panci ke fluida dan fluida ke dinding panci, dengan masing-masing nilai kalor optimum yang diterima sebesar $9,80 \mathrm{~kW}$ (pukul 10.05, iradiasi terukur $790 \mathrm{~W} / \mathrm{m}^{2}$ ) dan 40,16 $\mathrm{kW}$ (pukul 11.35, iradiasi matahari terukur $120 \mathrm{~W} / \mathrm{m}^{2}$ ). Nilai $\mathrm{Q}_{3}$ merupakan laju aliran kalor dari fluida menuju dinding bagian dalam, oleh karena itu nilai kalor yang diterima oleh dinding dalam panci terjadi pada saat kondisi iradiasi surya terukur sebesar $120 \mathrm{~W} / \mathrm{m}^{2}$, atau disaat kondisi suhu dari dinding dalam menurun diakibatkan aliran kalor yang ada pada dinding dalam menuju ke dinding luar sistem.

Sedangkan kalor dilepaskan dari sistem ke lingkungan terjadi pada $\mathrm{Q}_{1}$ sebesar -37,47 $\mathrm{kW}$ pada pukul 12.50, dengan kondisi iradiasi surya terukur sebesar $140 \mathrm{~W} / \mathrm{m}^{2}$, dan Q4 = 197,98 kW pada saat kondisi iradiasi surya sebesar $210 \mathrm{~W} / \mathrm{m}^{2}$. Peristiwa pelepasan kalor dari sistem ke lingkungan terjadi diakibatkan karena adanya perbedaan suhu, sehingga untuk mencapai suatu kondisi kesetimbangan, kalor akan mengalir dari daerah yang bersuhu tinggi menuju daerah bersuhu rendah sesuai dengan ketentuan yang tercantum pada Hukum Termodinamika II.

\section{Analisis Efisiensi Sistem Panci Bertekanan}

Perhitungan efisiensi sistem dilakukan guna mengetahui tingkat efisiensi dari sistem panci bertekanan yang dipakai. Tingkat efisiensi dihitung berdasarkan dari nilai output kalor pada sistem dan pada fluida yang didapatkan dari pantulan iradiasi surya yang berasal dari reflektor, dibagi dengan nilai input iradiasi surya yang masuk ke dalam sistem. Data perhitungan efisiensi sistem panci dapat dilihat pada Tabel 4 berikut ini.

Tabel 5. Tingkat efisiensi sistem dengan fluida kerja air

\begin{tabular}{|c|c|c|c|c|c|}
\hline \multirow{2}{*}{ Waktu } & \multirow{2}{*}{$\begin{array}{l}\text { Iradiasi Matahari } \\
\qquad\left(\mathrm{W} / \mathrm{m}^{2}\right)\end{array}$} & \multicolumn{2}{|c|}{ Nilai Kalor (W) } & \multirow{2}{*}{$\begin{array}{c}\text { Iradiasi yang } \\
\text { Dipantulkan (W) }\end{array}$} & \multirow{2}{*}{$\begin{array}{c}\text { Efisiensi } \\
\text { Sistem } \\
(\%) \\
\end{array}$} \\
\hline & & Dasar-dalam & Fluida & & \\
\hline $10: 00$ & 790 & 48,00 & 112,00 & 1661,01 & 9,63 \\
\hline $10: 05$ & 790 & 105,33 & 420,00 & 1661,01 & 31,63 \\
\hline $10: 10$ & 800 & 85,33 & 414,40 & 1682,04 & 29,71 \\
\hline $10: 15$ & 780 & 81,33 & 375,20 & 1639,98 & 27,84 \\
\hline $10: 20$ & 830 & 44,00 & 235,20 & 1745,11 & 16,00 \\
\hline $10: 25$ & 850 & 108,00 & 375,20 & 1787,16 & 27,04 \\
\hline $10: 30$ & 820 & 44,00 & 302,40 & 1724,09 & 20,09 \\
\hline $10: 35$ & 850 & $-32,00$ & 123,20 & 1787,16 & 5,10 \\
\hline $10: 40$ & 890 & 121,33 & 274,40 & 1871,26 & 21,15 \\
\hline
\end{tabular}


JABER 2(1): 68-85 (2021)

Analisis Kinerja Sistem Panci Bertekanan - Ropiudin et al

\begin{tabular}{|c|c|c|c|c|c|}
\hline \multirow{2}{*}{ Waktu } & \multirow{2}{*}{$\begin{array}{l}\text { Iradiasi Matahari } \\
\left(\mathrm{W} / \mathrm{m}^{2}\right)\end{array}$} & \multicolumn{2}{|c|}{ Nilai Kalor (W) } & \multirow{2}{*}{$\begin{array}{c}\text { Iradiasi yang } \\
\text { Dipantulkan (W) }\end{array}$} & \multirow{2}{*}{$\begin{array}{c}\text { Efisiensi } \\
\text { Sistem } \\
(\%) \\
\end{array}$} \\
\hline & & Dasar-dalam & Fluida & & \\
\hline $10: 45$ & 800 & 25,33 & 140,00 & 1682,04 & 9,83 \\
\hline $10: 50$ & 880 & 93,33 & 257,60 & 1850,24 & 18,97 \\
\hline $10: 55$ & 900 & 74,67 & 274,40 & 1892,29 & 18,45 \\
\hline $11: 00$ & 910 & 69,33 & 274,40 & 1913,32 & 17,97 \\
\hline 11:05 & 980 & 12,00 & 302,40 & 2060,49 & 15,26 \\
\hline $11: 10$ & 940 & 13,33 & 274,40 & 1976,39 & 14,56 \\
\hline 11:15 & 1010 & 18,67 & 117,60 & 2123,57 & 6,42 \\
\hline $11: 20$ & 300 & 2,67 & 16,80 & 630,76 & 3,09 \\
\hline $11: 25$ & 180 & $-110,67$ & $-274,40$ & 378,46 & $-101,75$ \\
\hline $11: 30$ & 210 & $-46,67$ & $-140,00$ & 441,53 & $-42,28$ \\
\hline 11:35 & 120 & $-50,67$ & $-196,00$ & 252,31 & $-97,77$ \\
\hline $11: 40$ & 130 & $-74,67$ & $-235,20$ & 273,33 & $-113,37$ \\
\hline $11: 45$ & 110 & $-25,33$ & $-156,80$ & 231,28 & $-78,75$ \\
\hline $11: 50$ & 110 & 22,67 & $-95,20$ & 231,28 & $-31,36$ \\
\hline $11: 55$ & 120 & $-28,00$ & $-95,20$ & 252,31 & $-48,83$ \\
\hline $12: 00$ & 180 & $-12,00$ & $-61,60$ & 378,46 & $-19,45$ \\
\hline $12: 05$ & 130 & $-2,67$ & $-22,40$ & 273,33 & $-9,17$ \\
\hline $12: 10$ & 120 & $-5,33$ & 22,40 & 252,31 & 6,76 \\
\hline $12: 15$ & 110 & $-18,67$ & $-33,60$ & 231,28 & $-22,60$ \\
\hline $12: 20$ & 130 & $-16,00$ & $-56,00$ & 273,33 & $-26,34$ \\
\hline $12: 25$ & 140 & $-14,67$ & $-78,40$ & 294,36 & $-31,62$ \\
\hline $12: 30$ & 120 & $-14,67$ & $-22,40$ & 252,31 & $-14,69$ \\
\hline $12: 35$ & 110 & $-13,33$ & $-134,40$ & 231,28 & $-63,88$ \\
\hline $12: 40$ & 120 & $-22,67$ & $-123,20$ & 252,31 & $-57,81$ \\
\hline $12: 45$ & 130 & $-24,00$ & $-112,00$ & 273,33 & $-49,76$ \\
\hline $12: 50$ & 140 & $-24,00$ & $-140,00$ & 294,36 & $-55,71$ \\
\hline $12: 55$ & 140 & $-13,33$ & $-89,60$ & 294,36 & $-34,97$ \\
\hline $13: 00$ & 120 & $-32,00$ & $-56,00$ & 252,31 & $-34,88$ \\
\hline 13:05 & 110 & $-12,00$ & $-56,00$ & 231,28 & $-29,40$ \\
\hline $13: 10$ & 130 & $-13,33$ & $-112,00$ & 273,33 & $-45,85$ \\
\hline $13: 15$ & 210 & $-5,33$ & $-33,60$ & 441,53 & $-8,82$ \\
\hline $13: 20$ & 230 & $-13,33$ & $-151,20$ & 483,59 & $-34,02$ \\
\hline $13: 25$ & 220 & $-21,33$ & $-140,00$ & 462,56 & $-34,88$ \\
\hline 13:30 & 210 & $-8,00$ & $-28,00$ & 441,53 & $-8,15$ \\
\hline 13:35 & 230 & $-13,33$ & $-16,80$ & 483,59 & $-6,23$ \\
\hline $13: 40$ & 130 & $-5,33$ & $-56,00$ & 273,33 & $-22,44$ \\
\hline $13: 45$ & 110 & $-5,33$ & $-22,40$ & 231,28 & $-11,99$ \\
\hline $13: 50$ & 110 & $-5,33$ & $-31,92$ & 231,28 & $-16,11$ \\
\hline $13: 55$ & 110 & $-5,33$ & $-31,92$ & 231,28 & $-16,11$ \\
\hline $14: 00$ & 110 & $-5,33$ & $-31,92$ & 231,28 & $-16,11$ \\
\hline
\end{tabular}

Berdasarkan Tabel 5, menjelaskan bahwa efisiensi optimal yang dapat diperoleh dari sistem panci bertekanan yang digunakan dengan air sebagai fluida kerjanya adalah sebesar $31,63 \%$, 
pada saat kondisi iradiasi matahari sebesar $790 \mathrm{~W} / \mathrm{m}^{2}$. Untuk efisiensi panci ketika menggunakan minyak sayur sebagai fluida kerja disajikan pada Tabel 6 berikut ini.

Tabel 6. Tingkat efisiensi sistem panci dengan fluida kerja minyak sayur

\begin{tabular}{|c|c|c|c|c|}
\hline \multirow{2}{*}{ Waktu } & \multirow{2}{*}{$\begin{array}{l}\text { Radiasi Matahari } \\
\text { (W/m2) }\end{array}$} & \multicolumn{2}{|c|}{ Nilai Kalor yang diterima (W) } & \multirow{2}{*}{$\begin{array}{l}\text { Efisiensi } \\
\text { Sistem (\%) }\end{array}$} \\
\hline & & Dasar-dalam & Fluida & \\
\hline $10: 50$ & 1000 & 44,00 & 73,69 & 17,57 \\
\hline 10:55 & 1010 & 361,33 & 41,18 & 59,48 \\
\hline 11:00 & 1060 & 333,33 & 229,73 & 79,28 \\
\hline 11:05 & 1120 & 197,33 & 470,30 & 88,97 \\
\hline $11: 10$ & 1050 & 204,00 & 329,43 & 75,82 \\
\hline 11:15 & 1070 & 140,00 & 286,08 & 59,43 \\
\hline $11: 20$ & 1050 & 174,67 & 320,76 & 70,42 \\
\hline $11: 25$ & 1050 & 156,00 & 273,08 & 60,99 \\
\hline $11: 30$ & 990 & 97,33 & 192,89 & 43,75 \\
\hline $11: 35$ & 1050 & 162,67 & 255,74 & 59,48 \\
\hline $11: 40$ & 1070 & 74,67 & 182,05 & 35,81 \\
\hline $11: 45$ & 1080 & 84,00 & 177,72 & 36,17 \\
\hline $11: 50$ & 1000 & 93,33 & 151,71 & 36,57 \\
\hline $11: 55$ & 1060 & 102,67 & 162,55 & 37,34 \\
\hline $12: 00$ & 1080 & 109,33 & 182,05 & 40,27 \\
\hline $12: 05$ & 200 & $-296,00$ & 52,01 & $-182,08$ \\
\hline $12: 10$ & 1120 & 18,67 & $-132,20$ & $-15,13$ \\
\hline $12: 15$ & 1150 & 226,67 & 67,19 & 38,14 \\
\hline $12: 20$ & 1180 & 56,00 & 117,03 & 21,89 \\
\hline $12: 25$ & 320 & $-32,00$ & 88,86 & 26,52 \\
\hline $12: 30$ & 200 & $-388,00$ & $-110,53$ & $-372,04$ \\
\hline $12: 35$ & 210 & $-172,00$ & $-162,55$ & $-237,77$ \\
\hline $12: 40$ & 200 & $-142,67$ & $-162,55$ & $-227,77$ \\
\hline $12: 45$ & 200 & $-100,00$ & $-166,88$ & -199,17 \\
\hline $12: 50$ & 170 & $-73,33$ & $-125,70$ & $-174,75$ \\
\hline $12: 55$ & 210 & $-101,33$ & $-149,54$ & $-178,31$ \\
\hline $13: 00$ & 990 & 377,33 & $-69,35$ & 46,43 \\
\hline $13: 05$ & 670 & 134,67 & 97,53 & 51,73 \\
\hline $13: 10$ & 200 & $-8,00$ & 106,20 & 73,28 \\
\hline $13: 15$ & 210 & $-322,67$ & $-73,69$ & $-281,70$ \\
\hline $13: 20$ & 940 & 408,00 & 6,50 & 65,81 \\
\hline $13: 25$ & 900 & 81,33 & 130,04 & 35,05 \\
\hline $13: 30$ & 920 & $-4,00$ & 54,18 & 8,14 \\
\hline
\end{tabular}

Berdasarkan Tabel 7, bahwa nilai efisiensi optimal yang dihasilkan oleh sistem panci ketika menggunakan fluida kerja berupa minyak sayur sebesar $88,97 \%$ pada kondisi iradiasi matahari sebesar $1120 \mathrm{~W} / \mathrm{m}^{2}$. Intensitas radiasi matahari yang cenderung fluktuatif pula menyebabkan terjadinya pelepasan energi kalor yang berdampak pada tingkat efisiensi dari sistem itu sendiri, seperti halnya pada Tabel 7 saat kondisi iradiasi matahari sebesar $130 \mathrm{~W} / \mathrm{m}^{2}$ dan saat kondisi iradiasi matahari sebesar $210 \mathrm{~W} / \mathrm{m}^{2}$. Karakteristik panci presto menjadi faktor 
lain yang berpengaruh dalam hal ini, dikarenakan adanya campuran lapisan aluminium di bagian dasar panci, membuat panas cepat berpindah dari sistem ke lingkungan, sehingga nilai efisiensi sistem dalam menahan energi panas yang telah diterima menjadi turun.

Faktor lain yang berpengaruh adalah pada lapisan isolasi, dimana glasswool yang dipakai sebagai insulator (penahan panas) masih belum mampu menahan panas agar tetap di dalam sistem. Diperkirakan ketebalan dari lapisan glasswool yang dipakai kurang, sehingga panas yang ada di dalam sistem masih ada yang mengalir keluar.

\section{KESIMPULAN}

Berdasarkan pengukuran dan perhitungan data, maka dapat diambil beberapa kesimpulan diantaranya : (1) Suhu optimum yang dapat diraih dari prototipe sistem panci berdasarkan 2 data yang telah dipilih adalah pada bagian dasar-luar panci adalah $224,2{ }^{\circ} \mathrm{C}$, untuk bagian dasar-dalam panci sebesar $202,5{ }^{\circ} \mathrm{C}$, dinding-dalam panci $=131,2{ }^{\circ} \mathrm{C}$, tutup panci $=98,2{ }^{\circ} \mathrm{C}$, dan dinding-luar panci (tertutup glasswool) $=84,7^{\circ} \mathrm{C}$. (2) Prototipe sistem panci bertekanan ini dapat menghasilkan tekanan optimum sebesar 0,15 bar atau setara dengan $15 \mathrm{kPa}$ ketika menggunakan air sebagai fluida kerja, sedangkan ketika memakai minyak belum mampu menghasilkan tekanan. (3) Nilai kalor optimal prototipe sistem yang dihasilkan saat proses termal dari 2 data terbaik adalah $\mathrm{Q}_{1}=192,34 \mathrm{~kW}, \mathrm{Q}_{2}=9,8 \mathrm{~kW}, \mathrm{Q}_{3}=40,16 \mathrm{~kW}$, dan $\mathrm{Q}_{4}=$ $171,09 \mathrm{~kW}$. (4) Efisiensi termal optimum yang dapat dihasilkan oleh prototipe sistem panci bertekanan adalah sebesar 88,97\%, pada kondisi radiasi matahari $1120 \mathrm{~W} / \mathrm{m}^{2}$.

\section{DAFTAR PUSTAKA}

Aneka Mesin. (2013). Cara Kerja Alat Presto (On-line). http://anekamesin.com/cara-kerja-alatpresto.html. Diakses tanggal 30 Maret 2015.

Kreith, F. (1991). Prinsip-Prinsip Perpindahan Panas. Edisi Ketiga. Erlangga. Jakarta

Flick, D., Rocca, R., Doursat, D., \& Vasseur, J. (2007). Modelling Heat Transfer and Fluid Flow Inside a Pressure Cooker. Journal of 17th European Symposium on Computer Aided Process Engineering. Elsevier B.V. France

Hamid, A.A. (2007). Kalor dan Termodinamika. Diktat Kuliah. Universitas Negeri Yogyakarta. Yogyakarta.

Incroperara, F.P. \& Dewitt, D.P. (1982). Fundamental of Heat and Mass Transfer. Third Edition. John Wiley \& Sons, Singapore.

JFE Steel Corporation. 2004. Stainless Steel. JFE Steel Corporation. Japan

Long, C. \& Sayma, N. (2009). Heat Transfer 1st Edition (On-Line). http://bookboon.com/en/heat-transfer-ebook. Diakses tanggal 7 Desember 2015

Karim, S. (2010). Tinjauan Termodinamika Pada Sistem Partikel Tunggal Yang Terjebak Dalam Sebuah Sumur Potensial. Laporan Penelitian. Universitas Pendidikan Indonesia. Bandung.

Kementerian ESDM. (2006). Peraturan Presiden RI no. 5 tahun 2006 tentang Kebijakan Energi Nasional.2006(On-Line).

http://www.esdm.go.id/prokum/perpres/2006/perpres_05_2006.pdf. Diakses tanggal 3 Oktober 2015.

Manan, S. (2006). Energi Matahari, Sumber Energi Alternatif yang Effisien, Handal dan Ramah Lingkungan di Indonesia. Jurnal Diploma III Teknik Elektro. Universitas Diponegoro. Semarang

Novitasari, F. (2012). Desain Kompor Energi Matahari Dengan Menggunakan Media Lensa Air Sebagai Sumber Panas. Jurnal Desain dan Produk Industri. Institut Teknologi Sepuluh November. Surabaya. 
Pazzaglia, L. (2013). Pressure Cooker PSI FAQ: the stuff you didn't think to ask about pressure (On-Line). http://hipressurecooking.com/pressure-cooker-psi-faq-the-stuff-you-didntthink-to-ask. Diakses tanggal 30 April 2015.

Potter, M. C. \& Somerton, C.W. (1993). Schaum's Outline of Theory and Problems of Engineering Thermodynamics. McGraw-Hill. United States of America.

Saifuddin. (2000). Thermodinamika. Penerbit Erlangga. Jakarta.

Setiawan, H. \& Muchammad. (2011). Peningkatan Efisiensi Modul Surya 50 Wp Dengan Penambahan Reflektor. Jurnal Prosiding Seminar Nasional Sains dan Teknologi ke-2. Fakultas Teknik Universitas Wahid Hasyim. Semarang.

Susanto, E.P., Soemardi, B., \& Pane, I. (2012). Studi Penggunaan Dinding Foam Concrete (FC) dalam Efisiensi Energi dan Biaya untuk Pendinginan Udara (Air Conditioner). Thesis. Manajemen Rekayasa Konstruksi. Institut Teknologi Bandung

Suwito, Ardika, O. \& Darsopuspito, S. 2013. Analisa Performa Kolektor Surya Tipe Parabolic Trough Sebagai Pengganti Sumber Pemanas Pada Generator Sistem Pendingin Difusi Absorpsi. Jurnal Teknik Pomits Institut Teknologi Sepuluh November Surabaya. 2(3). 